\title{
Analysis of The Social And Cultural Values Contraining Increased African Apple Production In Anambra State of Nigeria
}

\author{
Enibe, D. 0. \\ Department of Agricultural Economics and Extension, \\ Chukwuemeka Odumegwu Ojukwu University, \\ Igbariam Campus, Anambra State, Nigeria
}

\begin{abstract}
This study analysed the social and cultural values constraining increased African Star Apple (ASA, Chrysophilum albidum) production in Anambra State of Nigeria. Data were collected using interview schedule on 80 respondents selected from six major assembly markets in six town communities of two Agricultural zones of the State. Ten respondents ( 5 men and 5 women) who are natives of the communities hosting the markets were selected through Snow ball sampling method (SBSM) from each of the markets. The interview schedule was mainly on yes or no questions. From the respondents, 7 in-depth interviews were conducted for detailed information on ASA important issues such as the crop's feast activities, children's song while under the trees and beliefs. Data were achieved with descriptive statistics such as percentage, frequency distribution and Tables. The study showed that: ASA production and consumption in the study area are by $100 \%$ constrained with social and cultural norms such as none planting, none harvesting, public ownership and free fruits collection. The result also reveals that the studied communities differ in their ASA fruit selling and buying norms and in ASA feast in the past and that they do not easily change their norms except on certain conditions such as knowledge gain and sensitization. The study inter alia recommends that effort to increase or commercialize its production by entrepreneurs requires orientation or sensitization of the tradition custodians in the communities and adequate protection of the trees in farm fields or plantations.
\end{abstract}

\section{INTRODUCTION}

In all the parts of the world, people access food, fruits, fodder, wood, medicine and other values from tree species (Laurent et al, 2012). In Africa, there are numerous interesting native tree species and they include Palm trees, Breadfruit (Treculia africana), oranges and African star apple (ASA). ASA is scientifically recognized as Chrysophilum albidum. ASA is in Nigeria recognized in different tribes by different names. For example, the Igbo call it udala or udara, It is known as Agbalumo in Yoruba, ehya by Igala and agwaluma in Hausa. In general, it is mainly a forest tree species whose natural occurrences have been reported in many eco-zones and in many countries including Nigeria, Cameroon, Niger, Uganda, and Cote d'lvoire (Amusa, Ashaye and Oladapo, 2003). ASA value varies 
in those tribal groups. It is one of those tree species that are seen in the traditional agroforestry system of Southeast Nigeria.

The tree and the fruit are variously used, regarded and appreciated in various ways in different cultural and sub cultural areas. The ASA fruit in some Igbo communities offers different values and they include snack, symbol of love, games, shed and feast. Its ripened fruit is eaten mostly as snack and relished by various age groups especially the children, girls and women (Amusa, Ashaye and Oladapo, 2003). The crude protein, carbohydrates and crude fat content of udala were respectively revealed to be $8.8 \%, 29.9 \%$ and 17.1\% (Adelaja, 1997). Studies have shown that ASA fruit contains a larger amount of ascorbic acid (1000 - 3,330 mg per $100 \mathrm{gm}$ of edible fruit) or up to 100 times that of oranges and 10 times of that of guava or cashew (Okoli, 2010; Laurent et al, 2012).

The fruit contains about 4-5 seeds depending on the variety. It is also reported to be a source of oil (Amusa, Ashaye and Oladapo, 2003). The seeds in Abagana and some Igbo town or village communities are used for elementary mathematics teaching to pupils and in playing traditional games such as Swell and "Ncho". The roots, leaves and the bark are reported to have medicinal values. Specifically, Adewusi (1997) reported that the bark is used for the treatment of yellow fever and malaria, while the leaves are used as skin softening and soothing material (emollients), skin eruptions treatment, treatment of diarrhoea and stomach-ache, which are as a result of infections and inflammatory reactions. These indicate that ASA is an important medicinal plant which can be used in industries for production of pharmaceutical products. The values of ASA suggest the need for its increased production and consumption.

Several studies and reports have been done on ASA as seen here above. For further examples, Amusa, Ashaye and Oladapo (2003) reported it to be a forest tree species which occur naturally in many countries. They added that the fruits are allowed to drop naturally from the trees. Okoli (2010) in his study provided a rationale for the use of ASA seeds and root extracts in Nigerian traditional medicine practice. Ureigh (2010) in his study concluded that both the sweet, very sweet or sour ASA provide nutrient supplements for both women and children in rural communities and that it should support better utilization of the tree species by domestic industries. Adebayo et al (2012) revealed that the crop has in recent times become a fruit of commercial value in Nigeria.

Most of the studies done on ASA concentrated on its nutritional, medicinal, and industrial utilization potentials as briefly discussed in section3.3. Available research articles suggest that little or no study have been conducted on the crop's sociology of production, gender issues and marketing problems. This suggests the need to understand whether there are social issues that may be limiting ASA increased production, marketing and utilization potentials. Such social elements may be the farmers and rural dwellers' cultural values such as norms, beliefs and gender issues. The problem of this paper is that ASA cultivation and harvesting situations, gender issues, social norms, marketing problems have not been identified. The other problem is that what have changed about ASA rules of conduct is unknown. These warrant the following research questions: Why do farmers in the study area not plant ASA trees or harvest their fruits? Are there gender issues in ASA production and management? Are there social barriers constraining increased ASA production and marketing? 
Enibe, D. O. (2020). Analysis of The Social And Cultural Values Contraining Increased African Apple Production In Anambra State Of Nigeria. Advances in Social Sciences Research Journal, 7(5) 134-144.

\section{Objectives Of The Study}

The broad objective of the study is to constraining increased production and consumption of in the study area. The specific objectives of the study are to:

1. Understand whether there is ASA tree planting and their fruits harvesting or not.

2. Identify the gender issues in ASA production and management,

3. Identify the social barriers constraining increased ASA production and management.

4. Make recommendation for increased ASA cultivation, consumption and utilization.

\section{Study Area}

\section{MATERIALS AND METHODS}

The study was conducted in Anambra State of Nigeria, West African sub region. The State lies between latitude 5038 ' $\mathrm{N}$ to $6047^{\prime} \mathrm{N}$. and longitude $6036^{\text {'E to }} 7021^{\prime}$ '. The State according to Enibe, Eze and Ugwuoke (2018) is bounded in the North by Kogi State, in the South by Imo State, in the east by Enugu State, in the west by River Niger and Delta State. Anambra State lies within the tropical rain forest region and in Southeast Nigeria where dry and rainy seasons are the major seasons. The State has 21 local government areas (LGAs), 4 agricultural zones (AZ) and assembly markets in her cities, towns and villages. As in most parts of Igbo land, each of the Igbo markets was named: Eke, Oye, Afor, and Nkwo (Enibe, Eze and Ugwuoke, 2018). The names of the towns hosting the markets are often attached to the markets for identification and location purposes. Sometimes, the name of the town's progenitor or location in a village community is added to the market's name for identification purposes. Enibe et al (2019) revealed that one Igbo week is equal to four days and that seven of the weeks which totals 28 days is counted a month. They added that 13 of the months yield 13 moon lights (lunar months) and 364 days which is counted an Igbo traditional year.

\section{Sampling Procedure and Sample Size}

Data for the study were collected from both secondary and primary sources. Secondary data were obtained from thesis, Books, and Journals. Primary data were purposively collected from men and women who are either natives or wives of men of the communities hosting the following six major assembly markets Awka and Aguata Agricultural zones: Eke Awka, Oye Achala, Oyeagu Abagana, Nkwo Igboukwu, Afor Ufuma, and Oye Achina. The markets were purposively selected because of various reasons. Eke Awka was selected because it is a capital city market. Oye Achala was purposively selected because the town is a popular agricultural community especially rice production and processing. Oye Agu Abagana was purposively selected for five reasons: First, it is one of the major assembly markets in Awka Agricultural zone of Anambra State. Second it is located almost at the centre of Anambra state. Third, it is located in a special village of Abagana named and called land of justice (Ama-Ene). Fourth, it is strategically located and contains a popular junction from where many parts of the state can be accessed. Finally, the market is located in a popular community (Abagana) with various cultural or social values and activities. Nkwo Igboukwu was purposively selected because it is located in one of the ancient Igbo communities where there was interesting archaeological discovery and because it is one of the most popular assembly markets in Aguata Agricultural zone of Anambra state. Afor Ufuma was purposively selected because it is one of the biggest assembly markets of the area where many fruits are supplied and demanded. Oye Achina was purposively selected because the town's logo has a kite that appears to be flying away after picking a fraction of fire which suggests that extra ordinary information may be obtained in the town and that any of the information may relate to change. 


\section{Sampling Method}

This study aimed to understand whether ASA: is planted and harvested or not, is on sale in each of the markets or not, has the norm of free collection of the fruits or not, is gendered in favour of men, women, children or a tree for all classes of people in the community hosting each of the markets, has a feast in the community or not, any ASA rule of conduct in each of the communities has changed or not. The study further aims to understand whether ASA norms are significant enough to be a barrier to adoption of its technologies in the study area.

In each of the eight markets named in section 2.2, 5 women and 5 men were selected through Snowball Sampling Method (SBSM) and interviewed using interview schedule. This gave a sub total of 40 women and 40 men and a grand total of 80 respondents from the eight markets. According to Rowland and John (2001); and Enibe et al (2019), SBSM is a linkage tracing research method that uses social network advantages of an approached respondent to offer a researcher with enlarging set of possible respondents. Using this method, the respondent approached and interviewed directs the researcher on where to access or reach another respondent for such interview. In turn, the respondent offers information about the other respondents and following this procedure, the researcher collects information from the number of respondents as scheduled. This is one of the established systems of identifying hidden population and collecting their data (Enibe et al, 2019; Rowland and John (2001). In-depth interviews were conducted on the respondents who rose important issues that are related to ASA and such information include ASA feast, stoppage of ASA feast and reason for the stoppage, gender issues in ASA feast and children's song while waiting for the fruit's fall.

\section{Data Analysis}

Data were analyzed using descriptive statistics such as percentage, frequency distributions and Tables.

\section{Planting of ASA}

\section{RESULTS AND DISCUSSION}

Table 1 reveals that all the respondents (100\%) in the study area reported that they did not cultivate any of the ASA trees. In-depth interviews conducted on some of the respondents revealed that none cultivation of the plant is because of the existing none planting norm and beliefs about the tree such as belief that it is child and belief that it sprouts and grow on its own. The result indicates that the majority of the ASA trees in the study area were not planted by those on whose land they stood. The result also indicates that none planting norm of the tree and beliefs about it can be a barrier to adoption of ASA technologies in the study area.

The result identifies a crop which it's social and cultural values can be a barrier to its increased cultivation. The result is in tandem with several studies which established that norms can be a barrier to diffusion of innovation or change (Rogers, 1983; Hu et al., 2006; Jones, 2010; Veen, 2010). The result also agrees with Jonsson et al. (2011) who in the adoption study of energetic crops in Sweden, opined that factors related to values are equivalently important as economic factors. The result further agrees with $\mathrm{Hu}$ et al (2006) who in a study done in three Nebraska counties (Otoe, Seward and Fillmore) to better understand farmers' forecasting uses of their values, social norms, beliefs, and felt problems, showed that social influence was significant at more than 95\% level of confidence. In addition, the result with Enibe (2018) who revealed that values in many cultural 
Enibe, D. O. (2020). Analysis of The Social And Cultural Values Contraining Increased African Apple Production In Anambra State Of Nigeria. Advances in Social Sciences Research Journal, 7(5) 134-144.

areas are implicit, but still respected in the areas and that they sometimes exact negative effects on the productivity of some crops and animals species or adoption of their technologies. .

\section{ASA ownership (gender sensitivity)}

Table 1 reveals that all the respondents $(100 \%)$ in the study area indicated that ASA is not gendered in favour of any class of persons, but generally owned by the men, women, youth and children. Also, Table 1 shows that $100 \%$ of the respondents in the six study markets/communities accepted that their ASA general ownership norm has not been changed. However, in-depth interview at Achala (a woman of 55 revealed that ASA fruit is the food of children which are also taken by other classes of people. An in-depth interviewee at Abagana (a traditional man of about 65) revealed that it is believed to be child and hence not marketed because children are not supposed to be on sale. He added that women of the community celebrate the tree in a feast named after it while men play the role of organizing masquerades for activities on the trees in efforts to reaffirm the established norm of none harvesting of the fruits and for sanctioning offenders.

One of the in-interviewees (a woman of about 70) while recalling their childhood days under the trees revealed that "ASA fruit is the food of children and that they spend more time staying under the trees while on the wait for the fall of the fruits. Under the trees, we spent a lot of our leisure time playing, telling stories and singing while on the wait for the fall of the fruits. At the fall of any of the ripened fruits, it is often picked by either the most lucky one who might have stayed closer the fallen point of the fruit or the fastest one when it falls further away from our waiting areas. Despite their rush for the fallen fruit, we most often share it among our beloved ones. On this, some may get and happily lick only one of the coated seeds while others share the pulp. While under the trees sometimes we sang different songs. An example of such Igbo songs is: "Udalam daa, daa, daa,daa; dalu nwaenwenne, dalu nwaenwenna. Enu uwa bu olili, onye nosia onaba. Nwunyennam, gota udala n'afia, lachawo nwaenwenne, lachawo nwaenwenna, enuwa bu olili, onye nosia onaba".

The song is in Igbo and it seems meaningful, requesting, sentimental, nostalgia, persuasive and rhetoric. The first phrase is a plea for her ASA fruit to fall for her to pick and lick. The second phrase is another plea for the fruit to fall for collection by both the motherless and the fatherless. The second stanza is a story about her mother's wicked co classificatory wife who bought ASA fruits in a market and licked them without sharing with either the motherless or the fatherless and without knowing that people are visitors to the world who go home (dies) at the end of their visits \{life time). From the songs wordings it can be interpreted that, the children believe that each of the fruits is destined to ripen to fall for collection by a particular individual. This is in line with the belief in some village communities that breadfruit decides who will consume it from its fruiting time.

The result shows that ASA is not gendered in favour of either men or women, but regarded a general fruit tree in many communities with different classes of people in some communities being involved in its management. The result further revealed that ASA is gender biased in certain areas which include its consumption, feast, management and sanctioning against its established norms violation. This is because of three reasons. First, the result revealed that children do consume more of the fruits due to their longer stay under the trees. Second, the result revealed that the ASA feast is gender biased in favour of women. Finally, the ASA tree none harvesting norm is revealed to be the role of the men and boys especially those that belong to the masquerade society. 
The result is unlike the situation where some crops such as yam and cocoyam in Igbo cultural areas are said to be respectively gendered as a male and a female crop (Njoku and Chuchuma (2015, Enibe, 2017). The reason for this is the existing norm in this cultural area which might be because they believe that the crop is a nutritious one which should benefit all people both those on whose land the trees stand and none owners of the land. The result is in line with Baryard et al. (2007) and Enibe (2017) who reported that gender is one of the important socioeconomic factors which influence adoption of agroforestry. The result also agrees with Peterman et al (2011) and Enibe (2017) who revealed that there is the need to reveal gender bias in the production, ownership, management and marketing of different crops in different communities, cultural areas, and agricultural zones of different countries. A reason for this is because many crops differ in their gender bias in the aforesaid areas. .

\section{ASA Marketing Norms}

Table 1 shows that none selling of ASA fruits is a social norm (100\%) in three (Oye Agu Abagana, Nkwo Igbo Ukwu and Oye Achina) of the six study markets/communities while it is not (100\%) in the other three (Eke Awka, Oye Achala and Nkwo Ufuma). The Table however reveals that selling of ASA fruits was an acceptable social norm in Achina, but was later changed to none selling. The Table further reveals that the communities can sometimes change their social custom in favour or against increased production of certain crops. An in-depth interviewee, (a woman of about 70) revealed that the social custom of many communities does not allow the selling of ASA fruit in the market because it is believed to be child and because child should not be for sell as gift from God. On the contrary, Table 1 shows that buying of ASA fruits

The result reveals that communities of the study area differ in their social custom of selling or not selling ASA fruits and may also differ in their other social values of things including those of products, crops and animals. The result suggests the need to understand the existing social custom of crops and animals in different agricultural communities. This is because it might be of help to development workers for deeper understanding of the communities and enable them take appropriate decisions while diffusing crops and animals' technologies. The result indicates that ASA fruits have little or no commercial values in some rural communities of the study area and that effort to sell ASA fruits in those communities may attract anger or sanction by the custom custodians of those village or town communities. The study agrees with Enibe (2018) who found that the beliefs and norm in a social system sometimes exact negative effects on the productivity of some species of plant and animals as well as in adoption of agricultural innovations. The result, however, contradicts Adebayo et al (2012) and Oboh, Aluyor, and Audu (2009) who reported that ASA have commercial value in Nigeria. This may be because values people place on crops differ in different cultural areas even within a tribe. In evidence, the study of Adebayo et al (2012) and that of Oboh, Aluyor, and Audu (2009) were laboratory analysis while this study is community based. Specifically, that of Adebayo et al (2012) was on ASA seed oil solvent extraction and characterization while that of Oboh, Aluyor, and Audu (2009) was on ASA use for the removal of Metal ions from aqueous solution.

\section{ASA free fruit collection norm}

Table 1 shows that free collection of ASA fruits (100\%) from their trees is an acceptable or existing social norm in the study area irrespective of whether the tree is in the accessible home gardens, farm fields, village squares or in any other public places. The result indicates that free ASA fruit 
Enibe, D. O. (2020). Analysis of The Social And Cultural Values Contraining Increased African Apple Production In Anambra State Of Nigeria. Advances in Social Sciences Research Journal, 7(5) 134-144.

collection is a general custom in the study area and that free collection of the fruits can be a barrier to commercial production of the crop. An in-depth interviewee (an Achala woman of about 60) suggested that any idea or decision of an entrepreneur to establish ASA plantation for commercial or industrial utilization should be followed with either fencing of the plantation or public announcement for people to be aware and not approach the trees with the fruits' established rule of conduct. The result is in agreement with Enibe (2018) who in the study of the social barriers constraining increased breadfruit tree cultivation in Southeast Nigeria found that systems norm of free fruit collection (34.14\%) is a significant reason for limited planting of the trees in farm fields of some communities. The difference is that, the results from breadfruit is significant at $34.14 \%$ and limited to the trees in farm fields while that of ASA fruits is $100 \%$ and extended to fruits from the trees in other places such as front yards of people's homes and other accessible private and public places. This study is in tandem with the study by Hu et al (2006) at three Nebraska countries of Otoe, Seward and Fillmore which found social influence to be statistically significant at $95 \%$ confidence level.

\section{ASA feast}

\section{Table 1 reveals that only one out of the six study communities had ASA feast.}

An interviewee (a woman of about 70 who is a native of Ifite-Dunu in Dunukofia LGA,but married at Abagana in Njikoka LGA and who in the past participated in the feast) revealed that "ASA feast was celebrated in some communities of Njikoka, Dunukofia and Idemili LGAs. In Abagan, it was celebrated during the ripening of the fruit (between February and April of every year) with delicious yam porridge prepared with hen meat and other condiments. The ASA feast funding was normally on the same day in the town, but in groups of classificatory wives who through contributions funds it. The feast lasts for just a few hours unlike that of cocoyam that lasts for four days with men, women, young men and children involved in different ways. The cultural activities of ASA feast include traditional prayer with cola nut by the eldest classificatory wife, traditional make up by the women, singing and dancing under the tree, decoration of the tree which include the protective rubbing of ASA fruits on the tree trunks, offer of a special meal to the eldest classificatory wife, yam porridge eating and drinking of raffia palm wine".

The result shows that ASA feast is not a feast in many communities of the study area, but was a women feast in Abagana and in some others. Maurice (2012) defined feast as an annual religious celebrations. The result agrees with Enibe (2017) who reported that some crop in some Southeast Nigeria village or town communities are remembered with annual feasts named after the crop. From the interviewee's statement, it can be interpreted that ancient women had good indigenous knowledge of the chemical properties of ASA. This is because they had the idea of rubbing rubbed the fruit's pulp on the tree trunks as emolients and materials for decorating, protecting or even softening the tree trunks. In evidence, ASA is reported to contain $90 \%$ anacardic acid, which is used in industries for wood protection and as resin source (Amusa, Ashaye and Oladapo, 2003). The result suggests that ASA is an important tree that warrants increased production for industrial utilization. The information suggests the need for further studies to understand if ASA pulp contains emollients and if it can be a good material for production of glossy skin or hair pomades.

\section{Changes in ASA norms}

Table 1 reveals that all the study communities did not change their ASA social norms variables except in Achina where the norms of the crop's selling or buying were reported to have changed to 
none selling or buying. An in-depth interviewee (a woman of about 55 from Achina) revealed that the norms were changed on the intervention of the community's traditional leaders upon discovery that selling of ASA fruits is not good. Another in-depth interviewee in Abagana (a woman of about 75) revealed that "ASA feast no longer hold as from 1975 because most of them became Christians which resulted to contradiction and incompatibility in the women's funding and participation in the feast". The result indicates that social systems do not easily change their existing social norms except upon certain situations and or discoveries. The result further indicates that the changes reported on ASA were due to changes in knowledge which resulted in the stoppage of ASA fruit selling in Achina and change of many women in Abagana and other communities from traditional religion to Christianity which caused the stoppage of ASA feast.

The result firmly agrees with $\mathrm{Hu}$ et al (2006) who stated that farm families have inclinations to dwell or abide by their existential social values and norms. The result is in disagreement with Nnadi and Amaechi (2004) who stated that all social systems experience some alterations in their social structure and function within a space of time. This may be because only social issues of ASA were investigated and not all social issues in those communities. The result however, agrees with Nnadi and Amaechi (2004) who reported that aspects of people's social life do change and that they may take place in different ways with or without man's intervention.

Changes in the social systems could be referred to as social or cultural change. Social change is defined as the process by which modifications take place in the interaction and actions of people in communities or social systems Onuoha and Nnadi (1999). Such changes could be on attitudes, values such as norms and beliefs, cultural products, symbols and or method of greetings as found in uncertain time of virus worries. This is exampled in 2020 when many people around the world changed their greeting styles and stopped shaking hands due to corona virus disease pandemic which is also called COVID-19 pandemic. On the other hand, cultural changes are changes in knowledge, religion, artefact and art-forms such as sports, drama, feasts, music, dancing and literature while social change is limited to social relationships or interactions and their equilibriums (Nnadi and Amaechi, 2004). It is however known that cultural change and social change are interwoven because a change in one directly or indirectly leads to a change in the other. The result of this study indicates that the changes reported on ASA were due to changes in knowledge which resulted in the stoppage of ASA fruit selling in Achina and change of many women in Abagana from traditional religion to Christianity which caused the stoppage of ASA feast in the town and in some other towns or village communities.

Social change causes are according to Nnadi and Amaechi (2004) are classified into endogenous and exogenous factors. They revealed that endogenous factors are the ones which are domain in a social system which can cause social or cultural changes and that endogenous factors are also classified into episodic and predictable changes. Episodic changes are the ones that are not predictable and they can be as a result of invention or disease outbreak as aforesaid while predictable change could arise from such things as conflict, contradictions, incompatibilities and social problems (Nnadi and Amaechi, 2004). This is exampled in the case of stoppage of ASA feasts as seen here before which arose due to the change of the women from traditional religious way of life to Christianity. The exogenous factors on the other hand are the ones that are foreign to a social system and they according to Nnadi and Amaechi (2004) include contact with people of other cultures, colonization and invasion. 
Enibe, D. O. (2020). Analysis of The Social And Cultural Values Contraining Increased African Apple Production In Anambra State Of Nigeria. Advances in Social Sciences Research Journal, 7(5) 134-144.

\section{Table 1: Distribution of the Respondents According to ASA Social and Cultural Norms (Rule of} Conduct)

\begin{tabular}{|c|c|c|c|c|c|c|c|c|c|c|c|c|}
\hline \multirow{2}{*}{$\begin{array}{l}\text { arket name/Norms } \\
\text { Kind of Norms }\end{array}$} & \multicolumn{4}{|c|}{ Norms existing } & \multicolumn{8}{|c|}{ Change in existing norm } \\
\hline & Yes & Freq & $\%$ & No & Freq & $\%$ & Yes & Freq & $\%$ & No & Freq & $\%$ \\
\hline \multicolumn{13}{|l|}{ Eke Awka, Awka South LGA } \\
\hline ASA planting & Yes & 0 & 0 & No & 10 & 100 & Yes & 0 & 0 & No & 10 & 100 \\
\hline ASA ownership & Yes & 0 & 0 & No & 10 & 100 & Yes & 0 & 0 & $\mathrm{No}$ & 10 & 100 \\
\hline ASA harvesting & Yes & 0 & 0 & No & 10 & 100 & Yes & 0 & 0 & No & 10 & 100 \\
\hline ASA buying & Yes & 10 & 100 & No & 0 & 0 & Yes & 0 & 0 & No & 10 & 100 \\
\hline Strangers allowed to sell/buy & Yes & 10 & 100 & No & 0 & 0 & Yes & 0 & 0 & No & 10 & 100 \\
\hline ASA selling & Yes & 10 & 100 & No & 0 & 0 & Yes & 0 & 0 & No & 10 & 100 \\
\hline Free fruit collection & Yes & 10 & 100 & No & 0 & 0 & Yes & 0 & 0 & No & 10 & 100 \\
\hline ASA love feast by women & Yes & 0 & 100 & No & 10 & 100 & Yes & 0 & 0 & No & 10 & 100 \\
\hline \multicolumn{13}{|l|}{ Total } \\
\hline \multicolumn{13}{|l|}{ Oye Achala, Awka North LGA } \\
\hline ASA planting & Yes & 10 & 100 & No & 0 & 0 & Yes & 0 & 0 & No & 10 & 100 \\
\hline ASA ownership & Yes & 0 & 0 & No & 0 & 0 & Yes & 0 & 0 & No & 10 & 100 \\
\hline ASA harvesting & Yes & 0 & 0 & No & 10 & 100 & Yes & 0 & 0 & No & 10 & 100 \\
\hline ASA buying & Yes & 10 & 100 & No & 0 & 0 & Yes & 0 & 0 & No & 10 & 100 \\
\hline Strangers allowed to sell/buy & Yes & 10 & 100 & No & 0 & 0 & Yes & 0 & 0 & No & 10 & 100 \\
\hline ASA selling & Yes & 10 & 100 & No & 0 & 0 & Yes & 0 & 0 & No & 10 & 100 \\
\hline Free fruit collection & Yes & 10 & 100 & No & 0 & 0 & Yes & 0 & 0 & No & 10 & 100 \\
\hline ASA love feast by women & Yes & 0 & 0 & No & 10 & 100 & Yes & 0 & 0 & No & 10 & 100 \\
\hline \multicolumn{13}{|l|}{ Total } \\
\hline \multicolumn{13}{|c|}{ Oyeagu Abagana, Njikoka LGA } \\
\hline ASA planting & Yes & 0 & 0 & No & 10 & 100 & Yes & 1 & 10 & No & 10 & 100 \\
\hline ASA ownership & Yes & 10 & 100 & 0 & 0 & 0 & Yes & 0 & 100 & No & 10 & 100 \\
\hline ASA harvesting & Yes & 0 & 0 & No & 10 & 100 & Yes & 0 & 0 & No & 10 & 100 \\
\hline ASA buying & Yes & 0 & 0 & No & 10 & 100 & Yes & 0 & 0 & No & 10 & 100 \\
\hline Strangers allowed to sell/buy & Yes & 0 & 0 & No & 10 & 100 & Yes & 0 & 0 & No & 10 & 100 \\
\hline ASA selling & Yes & 0 & 0 & No & 10 & 100 & Yes & 0 & 0 & No & 10 & 100 \\
\hline Free fruit collection & Yes & 10 & 100 & No & 10 & 100 & Yes & 0 & 0 & No & 10 & 100 \\
\hline ASA feast & Yes & 10 & 100 & No & 0 & 0 & Yes & 10 & 100 & No & 0 & 0 \\
\hline \multicolumn{13}{|l|}{ Total } \\
\hline \multicolumn{13}{|l|}{ Afor Ufuma, Aguata LGA } \\
\hline ASA planting & Yes & 0 & 0 & No & 10 & 100 & Yes & 0 & 0 & No & 0 & 100 \\
\hline ASA ownership & Yes & 0 & 0 & No & 10 & 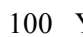 & Yes & 0 & 0 & No 1 & 10 & 100 \\
\hline ASA harvesting & Yes & 0 & 0 & No & 10 & 100 & Yes & 0 & 0 & No & 10 & 100 \\
\hline ASA buying & Yes & 10 & 100 & No & 0 & 0 & $\mathrm{Ye}$ & 0 & 0 & No & 10 & 100 \\
\hline Strangers allowed to sell/buy & Yes & 10 & 100 & No & 0 & 0 & Yes & 0 & & No & 10 & 100 \\
\hline ASA selling & Yes & 0 & 0 & No & 10 & 100 & Yes & 0 & 0 & No & 10 & 100 \\
\hline Free fruit collection & Yes & 10 & 100 & No & 0 & 0 & Yes & 0 & 0 & No & 10 & 100 \\
\hline ASA feast by women & Yes & 0 & 0 & No & 10 & 100 & Yes & 0 & 0 & No & 10 & 100 \\
\hline \multicolumn{13}{|l|}{ Total } \\
\hline \multicolumn{13}{|l|}{ Nkwo Igboukwu, Aguata LGA } \\
\hline ASA planting & Yes & 0 & 0 & No & 10 & 100 & Yes & 0 & 0 & No & 10 & 100 \\
\hline ASA ownership & Yes & 0 & 0 & No & 10 & 100 & Yes & 0 & 0 & No & 10 & 100 \\
\hline ASA harvesting & Yes & 0 & 0 & No & 10 & 100 & Yes & 0 & 0 & No & 10 & 100 \\
\hline ASA buying & Yes & 0 & 0 & No & 10 & 100 & Yes & 0 & 0 & No & 10 & 100 \\
\hline Strangers allowed to sell/buy & Yes & 0 & 0 & No & 0 & 0 & Yes & 5 & 50 & No & o 5 & 100 \\
\hline ASA selling & Yes & 0 & 0 & No & 10 & 100 & Yes & 10 & 100 & No & 101 & 100 \\
\hline Free fruit collection & Yes & 0 & 0 & No & 10 & 100 & Yes & 0 & 0 & No & o 10 & 100 \\
\hline ASA love feast by women & Yes & 0 & 0 & No & 10 & 100 & Yes & 0 & 0 & No & 10 & 100 \\
\hline Total & & & & & & & & & & & & \\
\hline Oye Achina, Aguata LGA & & & & & & & & & & & & \\
\hline ASA planting & Yes & 0 & 0 & No & 10 & 100 & Yes & 0 & 0 & No & o 10 & 100 \\
\hline ASA ownership & Yes & 0 & 0 & No & 10 & 100 & Yes & 0 & 0 & No & o 10 & 100 \\
\hline ASA harvesting & Yes & 0 & 0 & No & 10 & 100 & Yes & 0 & 0 & No & o 10 & 100 \\
\hline ASA buying & Yes & 10 & 100 & No & 0 & 0 & Yes & 10 & 100 & No & $\begin{array}{ll}0 & 0\end{array}$ & 0 \\
\hline Strangers allowed to sell/buy & Yes & 10 & 100 & No & 0 & 0 & Yes & 10 & 100 & No & {$\left[\begin{array}{ll}0 & 0\end{array}\right.$} & 0 \\
\hline ASA selling & Yes & 10 & 100 & No & 0 & 100 & Yes & 10 & 100 & $\mathrm{No}$ & To & 0 \\
\hline Free fruit collection & Yes & 10 & 100 & No & 0 & 0 & Yes & 0 & 0 & & No 10 & 100 \\
\hline $\begin{array}{l}\text { ASA love feast by women } \\
\text { Total }\end{array}$ & Yes & 0 & 0 & No & 10 & 100 & Yes & 0 & 0 & $\mathrm{No}$ & No 10 & $0 \quad 100$ \\
\hline
\end{tabular}

Source: Field survey, 2020. Key: Freq = Frequency, \% = Percentage, 


\section{CONCLUSION AND RECOMMENDATIONS}

The study showed that: ASA production and consumption in the study area are by $100 \%$ constrained with social and cultural norms such as none planting, none harvesting, public ownership and free fruits collection.

Effort to increase or commercialize its production by entrepreneurs requires orientation or sensitization of the tradition custodians in the communities and adequate protection of the trees in farm fields or in plantations.

Social Institutions and ministries with large land spaces should organize to plant the trees in suitable places of their land areas such as experimental farms or in strategic locations as shed trees and for increased consumption of their fruits by students and other sets of people in the institutions.

The Anambra State Ministry of information, Primary Health Development Agency, Extension agencies, and Nongovernmental Organizations should organize to educate people and entrepreneurs on the nutritional values of ASA for their fruits increased consumption and industrial utilization.

Further studies on ASA need to be conducted for understanding ASA fruits' cosmetics values for their possible utilization by cosmetic industries and urban marketing information. These may reveal their possible utilization as raw material in cosmetics industries and sources of the fruits marketed in Anambra state major markets.

\section{References}

Adebayo, S. E., Orhevba, B. A. Adeoye, P. A., Musa, J J., and Fase, Olabimpe Jumoke (2012).Solvent Extraction and Characterization of Oil from African Star Apple. (Chrysophyllum Albidum) Seeds. Academic Research International, 3, 2, $178-183$.

Adelaja BA (1997). Observations on the Pests and Diseases of Chrysophyllum albidum in Nigeria. In: Proceedings of a National workshop on the potentials of the star Apple in Nigeria (eds) Denton OA, Ladipo DO, Adetoro MA, Sarumi MB, 117-121.

Adewusi HA. (1997). The African Star Apple Chrysophylum albidum indigenous knowledge IK from Ibadan, Southwestern Nigeria. In: Proceedings of a National workshop on the potentials of the star apple in Nigeria (eds) Denton OA, Ladipo DO, Adetoro MA, Sarumi MB, 25-33.

Amusa, N. A., Ashaye, O.A. and Oladapo, M. O. (2003). Biodeterioration of the African star apple (Chrysophylum albidum) in storage and the effect on its food value. African Journal of Biotechnology, 2, 3, 56-59.

Bayard, B., Curtis, J. M. \& Dennis, S. A. (2007). The Economics of Adoption and Management of Alley Cropping in Haiti. Journal of Environmental Management,84, 62-70.

Enibe D. 0. (2017). Analysis of the Reasons for Limited Planting of Traditional and Improved breadfruit (Treculia africana) trees in Southeast Nigeria. UnpublishedPhD thesis, School of Agriculture, Policy and Development, University of Reading, United Kingdom

Enibe,D. O., Eze, A. O. and Ugwuoke, B. C. (2018). Economics of Pineapple Marketing in Anambra State, Nigeria). Journal of Agricultural Extension, 22, 2, 161-168.

Enibe D. O., Nwobodo, E. C., Nworji, M. J. and C. A. Okonkwo, C. A. (2019). Economic Analysis of Cocoyam Marketing in Anambra Agricultural Zone of Anambra State, Nigeria. Asian Journal of Agricultural Extension, Economics \& Sociology, 29, 3, 1-10. 
Enibe, D. O. (2020). Analysis of The Social And Cultural Values Contraining Increased African Apple Production In Anambra State Of Nigeria. Advances in Social Sciences Research Journal, 7(5) 134-144.

Hu, Q. I., Lisa M., Zillig P., Lynne, G. D., Tomkins, A. J, Waltman, W. J., Hayes, M. J., Hubbard K G, Artikov, I. H, Stacey J., Wihite, D. A. (2006). Understanding farmers' forecast use from their beliefs, values, social norms and perceived obstacles. Journal of Applied Meteorology and Climatology. 45: 1190-1201.

Jones L. (2010). Overcoming social barriers to adaptation. Overseas Development Institute. Background Note. ODI at 50: Advancing Knowledge, Shaping Policy, Inspiring Practice.Available online at: www.odi.org.uk/50years.

Jonsson AC, Ostwald M, Asplund T, Wibeck V. (2011). Barriers to and drivers of the adoption of energy crops by Swedish farmers: An empirical study. World Renewable Energy Congress Linkoping, Sweden. 2509-2515.

Laurent, G. H., Toussaint, O. L., Franois, G. G., Lisette, E. A. And Brice, S. (2012).Ethno-botanical study of African Star Apple (Chrysophyllum G. Don) in the Southern Benin (West Africa). Journal of Ethnobiology and Ethnomedicine, 8, 40, $1-10$.

Maurice Waite (2012). Oxford English Dictionary. Oxford University Press, Great Britain.

Njoku, J. I. K and Chukwuma, E. O. (2015). Culture and Agricultural Development in Nigeria. In Contemporary issues in Agricultural Extension and Rural Development. Department of Agricultural Extension and Rural Development, Michael Okpala University of Agriculture, Umudike, Nigeria.

Nnadi, F. N. And Amaechi, E. C. C. I. (2004). Rural Sociology for Development Studies. Benstel Enterprises, Owerri, Imo State, Nigeria.

Oboh, I.O., Aluyor, E.O. and Audu, T.O.K. (2009). Use of Chrysophyllum albidum for the Removal of Metal ions from aqueous solution. Scientific Research and Essay, 4,6, 632-635.

Onuoha, E. R. and Nnadi, F. N. (1999). Fundamentals of Agricultural Extension and RuralSociology. Sibon Books Limited, Ibadan, Nigeria.

Okoli, B. J. And Okere, O. S. (2010). Antimicrobial Activity Of The Phytochemical Constituents Of Chrysophyllum Albidum G.Don_Holl. (African Star Apple)

Peterman, A. Quisumbing, A., Behrman, J., and Nkonya, E. (2011). Understanding the complexities surrounding gender differences in agricultural productivity in Nigeria and Uganda. The Journal of Development studies, 47, 10, 1482-1509. Plant. Jorind, 8, 1, $301-311$.

Rogers, E. M. (1983). Diffusion of innovations, New York, The Free Press. 1-413.

Rowland A, John F. (2001). Accessing hidden and hard - to reach populations: Snowball Research strategies. Summer.;33.

Ureigho, U. N (2010). Nutrient Values of Chrysophyllum Albidum Linn African Star Apple as a Domestic Income Plantation Species. African Research Review, 4, 2, 51-56.

Veen, M. V. D. (2010). Agricultural innovation: Invention and adoption or change and adaptation? World Archaeology. 42: $1-12$. 